INTERNATIONAL JOURNAL OF CREATIVITY AND INNOVATION IN HUMANITIES AND EDUCATION

\title{
ON TRANSLATING GENDERED FIGURES OF SPEECH IN SHAKESPEARE INTO ARABIC
}

\author{
Nessma Abdel Tawab SALIM*
}

Faculty of Education, $6^{\text {th }}$ October University, Egypt

\begin{abstract}
English is not an inflected language, and apart from the recognized genders of male and female, there is a different category which is neuter. Neuter does exist in Arabic but is regarded arbitrarily as either male or female, somehow like French, for instance. When Shakespeare introduces fairies of different kinds, it is assumed that they are genderless: on the stage, they can be played by girls, or boys, according to the director's interpretation. However, in Arabic translation they are usually presented as female, though, in A Midsummer Night's Dream, Bottom deals with them as males. The names of the fairies can refer to whatever gender the translator wants, but the choice will inevitably affect the character of the play; it may conflict with the common view of the scene of the fairies in Act IV, or it may encourage a reading of Bottom's engagement with them as orgiastic. The story of translating Shakespeare into Arabic is, in a way, the story of departing from the criteria involved in what I have called the Arabic literary legacy. This movement took the form of introducing new literary genres, such as the novel, the short story, drama and a different kind of poetry- in form and content. This paper examines instances of adhering to the neuter as either male or female in Arabic, on account of Arabic culture, and how this adherence or lack of it in translation influences the meaning of the play's action.

Keywords

Gender, translation, plays, drama, orgiastic, and neuter.
\end{abstract}

\section{Introduction}

*Corresponding author: adminoct@o6u.edu.eg 
Of all Historical developments in literary and linguistic studies nothing has been so remarkable as that which led to the birth of Translation Studies. As thoroughly documented by eminent literary and linguistic scholars, the new discipline was born out of comparative literature which in the latter part of the twentieth century acquired an added vigor from the coming to maturity of Linguistics, an exact science, which seemed to contribute to the emerging sense of globalization, binding more languages and more cultures to one another. The unity in diversity heralded by the rise of the European Union helped to remove many of the hurdles hitherto thought to have been created by differences in language, hence in thought and culture among nations. The advent of the digital age was a major factor in impressing the need for all men and women to communicate and understand one another regardless of spatial and temporal distances. Translation thus thrived in a manner that could have shocked many of our ancestors: literary texts have been translated and exchanged, again at an unprecedented rate, and many classical works have been re-translated or readapted so drastically as to appear almost new-born. As the world experiencing the pleasures and pains of such unity in diversity, scholars began to look again into the vehicles of unity and those of diversity - human material on the one hand and the so-called "sad incompetence of human speech" on the other. People were now talking to one another in languages necessarily different and developing: they were reading and rereading the literature of different nations, past and present, but did they all grasp the same human material therein embodied? The literature of one nation may have influenced that of another, 
but what were the features that both share as human material ? Why should "literatures" be distinguished on the basis of language and formal aspects if they did in fact contain the same human material ? How are we to note such similarities and dissimilates of human material across linguistic barriers? These were some of the basic questions which gave an added power to comparative literature and at the same time to the study of translation as the means of transferring such human material from one culture to another as well as the transmission of culture itself down the centuries in many linguistic forms.

Well into the twenty-first century, the global village seems to be on the verge of an incredible unity, with the Arab world increasingly being part of that unity, challenging Eurocentrism, and reviving interest in the Arabic literary tradition and culture, long regarded adversarially by the old colonialists. More important, perhaps, has been the rise at around the same time of Translation Studies as an interdiscipline in the Arab world as elsewhere in the world. It is not without a sense of pride that in the odd thirty years from the late 1980 to the early decades of the 21 th century so many works on translation theory and practice were produced in Arabic, initially informed by advanced foreign scholarship but eventually gaining intrinsic independence. The same period has been marked by the flourishing of actual translation work commissioned in more than one Arab country. As a translation pundit has recently put it "translation has never had it so good."

\section{Translation Studies:}

As part of Translation Studies, scholars have sought to explore such heady question as what lies behind a translated text, in terms of ideology, philosophy, psychology etc., as well relating a given target (translated) text to a given matrix - literary or intellectual, native or foreign. The study of already translated texts has been quite fruitful in revealing how a 'target text' is related to home-produced ones, and whether it represented a natural addition, no matter how different, to the body of writing in the target language, as well as the associated questions of purpose (Skopos theory) and manipulation. As an independent text in its own right, the target text is mostly dealt with today as a work of art, and questions of equivalence are more or less categorically abandoned. On the other hand, the old idea of 
'honesty', even of 'accuracy', dies hard in the Arab world. The ghost of the source text looms large whenever a translated text is produced. All binary theories have thus been in vogue, such as communicative $V s$ semantic, fluent $V s$ resistant, foreignization $V s$ domestication etc. Most people still believe in the idea of a text as fixed or even as a monolithic structure which should have a single meaning and that such a meaning must be carried faithfully by the translated text. In most cases, however, that meaning is their own interpretation of the text. They may have been right or wrong in forming it, then came to believe it was absolute. In the case of Arabic literary and sacred texts, notoriously capable of many interpretations, readers were for a while quite happy with what they thought they had somehow gleaned. Things began to change, however, since the introduction in Arabic of hermeneutics - officially dating from the Schleirmacher (1768-1834) which marked new ways of approaching and interpreting texts. Being a theologian himself Schleirmacher had to fight a real battle in order to reconcile the criticisms of the Enlightenment with traditional Protestant Christianity. When such an effort, not to say such a 'battle', was about to be mounted in Arabic, the Quranic scholar responsible was ostracized, declared an apostate, and eventually died of grief. The point is that the idea of text has been so rigidly associated with Arabic religious texts that people's outlook on almost any text seems to carry the same canonical feeling. Consequently, although most learned people can accept the binaries referred to above as legitimate ways of rendering literary texts, some of them still use the nonsensical terms : 'literal' as opposed to 'free' translation techniques - George Steiner's Bete noir.

\section{Shakespeare in Arabic:}

The story of translating Shakespeare into Arabic is, in a way, the story of departing from the criteria involved in what I have called the Arabic literary legacy. This movement took the form of introducing new literary genres, such as the novel, the short story, drama and a different kind of poetry - in form and content. However, the cultural air was not ripe for the change. Early enough in the 20th century, Shakespeare's Romeo and Juliet was adapted as a musical, complete with original songs composed for the occasion, and with 
Ottoman music that pleased the 1912 audiences in Cairo. A little earlier, Muhammad Iffat had 'translated' Macbeth as a lyrical poem, following the vertical shape of Ancient Arabic poetry. This was never put on the stage, naturally, but, amazingly, found very many happy readers. Towards the end of the 1920 s, Shawqi ventured to imitate Shakespeare in form and content by writing verse drama that closely observed the idiom and metrics of ancient Arabic verse. About the same time appeared what must have been the novelty of novelties, namely the presentation of Shakespearean plays on the stage. A National Theatre Company was established by royal decree, and its director, Khalil Mutran, a French-educated Arabic poet of Egyptian-Lebanese extraction, was anxious to show Arab audiences something different from the comedies and melodramas adapted for the thriving commercial theatre. $\mathrm{He}$ translated Shakespeare himself - Macbeth, Hamlet, Othello and The Merchant of Venice. His translations were meant for the stage, and the Arabic used was classical, but quite actable, especially as the members of the company were highly educated. It is to be noted that when a novel was translated from say, French into Arabic (as Mutran's Shakespeare was) it had to be re-written in toto, as happened in the case of the master of classical Arabic prose, al-Manfaluti. Other translations in the inter-war period following suit. All major poets translated foreign works into the same high-falutin language, such as al-Aqqad, AlMazini and Taha Hussein. The creation of the Apollo school in 1932 marked but a slight departure from the classical ideal. Its poets had acquired the new Arabic popularized by the press (Modern Standard Arabic - MSA) and imbibed the English Romantic tradition which had flourished more than a century previously. Their translations of the romantics in particular showed that they had to use the ancient forms of verse, departing but little from their own creative output.

The Arab world had to wait for the end of World War II, however before a serious effort was made to translate the entire Shakespeare canon into Arabic: this mammoth project was master-minded by Taha Hussein himself, the so-called 'doyen' of Arabic letters. Working on the project were a motley assembly of early Egyptian university graduates with adequate Knowledge of foreign languages and a sound command of classical Arabic. Ambitious as the 
project was in inception, it had the sole express purpose of telling Arab audiences what Shakespeare 'said'. In other words, it had no literary theory, with the exception of being entirely in classical Arabic prose, mainly now in MSA. Meanwhile versions of Shakespeare's work were adapted, some re-written into Egyptian Arabic, for the stage and, occasionally, for the cinema. Some scholars took exception to the undifferentiated language of the target texts, particularly the fact that no one reading these translations felt that Shakespeare was a poet, first and foremost. Some translators, working outside the project, produced verse versions, but received little recognition, such as Abu Hadeed who translated Macbeth into Arabic verse using a composite Arabic metre which made it difficult to read. This was followed, many decades later by another verse translation of the same play by Zakher Ghibrial which was almost forgotten as soon as it was published. The only source of inspiration had been, ironically, there all the time, namely Ali Ahmad Bakatheer's Arabic Romeo and Juliet, published in 1938, which seemed to have influenced a whole generation of poets, in the post-World War II period. Bakatheer's version was in verse, a kind of metre called Khabab, which sounded easy to handle, much as both iambic and trochaic metres sound in English. This metre has the great value of sprezzature : it sounded easy to use though requiring a profound knowledge of Arabic phonology. Henceforth most aspiring poets would use it and, in the translation of verse, it offered an excellent alternative to the difficult and complex metres. Most verse drama in Arabic would thereafter be written in the same metre, legitimizing subsequent translations of verse in it. Much to the chagrin of the classical Arabist, the rich rhythmical resources of ancient Arabic - especially complex metres became less produced and, worse still, were practiced by less talented members of the rising generation. Another 'easy' enough metre, called rajaz, attracted the young and soon became used in original writing and in translation. Unfortunately these two metres are not highly respected by the traditionalists who lament the loss of variation in Arabic verse rhythms.

\section{Figures of Speech:}


Apart from the question of prose as opposed to verse, a formidable obstacle in any consideration of translating Shakespeare, there rose the question of translating his figurative language. To claim that all language is figurative, or tropic, as Hayden White maintains in his philosophical disquisition The Tropics of Discourse (1978), is to complicate the issue rather than simply it. On the other hand, to exclude, from our definition of figurative language, metaphor (similes, metonymies, allusion, etc.) would be to distort the actual, and still valid, meaning of a poetic image. Florence Marsh had tried in 1952 to replace the traditional figures by a "theory of symbolism" in the introduction to her Wordsworth's Imagery: A Study in Poetic Vision, reverting in effect to Caroline Spurgeon's definition of the image in her 1936 Shakespeare's Imagery and What it Tells Us. Useful for the purposes of Spurgeon, this definition seems to avoid the question of "tropicality" in White's sense altogether. Following in Spurgeon's footsteps, many students of imagery prefer to think of the image as any sense impression which is channeled through any of the body's sense to the brain. In this way the principle of figuration itself is jeopardized. It is deleterious to any concept of metaphor in the widest sense, which, looked at philosophically, means seeing something in terms of another, that is, as Spurgeon herself avows, the perception of unity in the diversity of things, or, as older poets have claimed, finding similitude in dissimilitude. Indeed, metaphor in this sense is like writing in verse, which imposes a kind of order on an otherwise unordered reality, engendering the sense of difference the reader of verse feels, whatever the form of the poem. To render the familiar unfamiliar has always been recognized as a function of true poetry, opening one's eyes to the wonders of life about us: and so is the opposite process, viz. to render the unfamiliar familiar by using a vehicle which is the trope, for ever entrusted with carrying a significant tenor which is the poet's vision. In her epoch-making $A$ Grammar of Metaphor, 1958, Christine Brooke-Rose established the categories of such vehicles more or less formally; but the categories keep multiplying with the advent of every truly talented poet.

\section{Wordplay:}


As a result of recent advances in the study of language, Word-play has been added to the time-honored categories of figurative language. As though the translation of imagery was not difficult enough, translators are now faced with the nearly unsurmountable hurdle of translating puns and irony. Both features seem to be language-specific, and, however serendipitous a rendering that seems to present the original pun or irony is, something may be lost in the process. Any judgment on the success of the translator in conveying a pun or an ironic statement to the target reader will be judged by a twofold criterion: first and more importantly, how far has the translator been successful in conveying the drift of the source word-play, that is, its significance within the source text, hence its original function; secondly, how the resultant figure coheres naturally with the target text, and how, consequently, it replicates its effect, putatively, on the reader. This difficulty is compounded by a necessary consideration of the assumed differences between the audience of the source text and that of the target text. If separated by considerable temporal or spatial distances, any attempt at equating the effects of source and target figures of speech will be fraught with dangers of misjudgment or over-simplification. Needless to say, over-concern about so-called equivalence in Locution, illocution or perlocution may be counter-productive: it may lead to the production of an unreadable text (if only an equivalent locution is sought after) a deviant text (if wild speculations about the intended meaning are made) or an utterly different text (if the perlocutionary effect is the sole object of the translator). Equivalence may appear to be the ultimate goal, but such is its illusory nature that most scholars today believe it to be the byword of every translated text.

\section{Gender Problematic:}

Tropes have been mostly classified in terms of form, Booke-Rose's book being the epitome of such an approach; but they have been thought of too in terms of the tenor rather than the vehicle. Cecil Day-Lewis, in his Poetic image (1947) distinguishes a category of common images and symbols, that is those used by all poets and normally carry the same meanings, regardless of time, place and culture. These are images of the heavenly bodies - 


\section{Gender Problematic:}

Tropes have been mostly classified in terms of form, Booke-Rose's book being the epitome of such an approach; but they have been thought of too in terms of the tenor rather than the vehicle. Cecil Day-Lewis, in his Poetic image (1947) distinguishes a category of common images and symbols, that is those used by all poets and normally carry the same meanings, regardless of time, place and culture. These are images of the heavenly bodies - 
the sun, the moon and the stars - as well as natural features that are familiar to all people, such as the earth, fire, water, air, animals and plants. These he calls "consecrated images", as opposed to those belonging to man-made life in society. So, apparently, this distinction should help the translator by confining the cultural dimension to the second category, but it does not. The words used in the first category are thought to be equally endowed with identical cultural implications in all languages but are not. Take the paramount example of the sun. Worshipped at one time in Egypt as God (nature) but is regarded as masculine in English, with connotations carried from ancient Greek as Phoebus (or as Apollo, God of sun) while the sun in Arabic is feminine. The question is more complex, however, for the Latin Phoebus comes from Greek Phoebus, giving us the modern name of Phoebe, which is a feminine name referring to Artemis, the goddess of the moon (identified with the Roman Diana) and does mean the moon as personified in poetry. The moon in English is feminine, and Diana is the goddess of chastity and purity; its etymology itself confirms its apotheosis: it is a contraction of Diviana, the Latin for divine (divus, god, ultimately from Sanskrit Diva which gave us the Latin Deus through the Ind-European Deiwas). The moon is, however, masculine in Arabic. There is no holiness attached to it, and its most common use in our daily life as well as in our popular poetry (and public lore) is to indicate a beautiful complexion, precisely a bright face, which is the original sense of Phoebus in Greek. Such complexities one rarely encounters when translating "informative" texts (as defined by Reiss) where one need hardly make an issue of the question of gender or, indeed, the mythical connotations of sun and moon, but it is in poetry that the question becomes all too relevant.

When Juliet calls on Phoebus to hurry in his chariot to the West, so that night comes more quickly for her appointed tryst with Romeo, how are we to imagine such an energetic rider, driving his fiery-footed steeds ? Should the translator change the rider's gender to accord with Arab tradition or keep the original masculinity as a curiosity ? Lewis Awad, an early translator of Shakespeare (and a scholar of great eminence) found a solution to the problem of invoking abstractions in verse, such as Greek and Roman gods and goddesses. In his own translations, he would add the simple (رب) or (ربة) that is, god or goddess, before 
the given name. In his translation of Shelley's Prometheus Unbound, his system worked. Echo, personified, becomes (ربة الأصداء) and, if he felt that the poet's mythopoeia imagination had created more such "beings", he would unhesitatingly resort to this solution (learned from him and widely used by $\mathrm{M}$. Enani in his Shakespearean translation). Alternatively the translator may ignore the gender, in this specific case, of the Sun: the translator may just call the sun "the sun".

Now consider the following invocation of Venus by Palamon in The Two Noble Kinsmen, jointly written by Shakespeare and Fletcher. In the Shakespearean parts, Palamon thus addresses Venus:

What godlike power

Hast thou not power? To Phoebus thou

Addest flames hotter than his; the heavenly fires

Did scorch his mortal son, thine him !

$$
\text { (V. i. 89-92) }
$$

In order words, Phoebus Apollo, doting on someone, allows his son, Phaethon, to drive the sun's chariot, which is a fatal venture, The first rhetorical question is easily enough understood: Venus has power over that of any other god or goddess. The second sentence is more or less straightforward, as the fire of love is hotter than that of the sun. The Arabic translator need not refer to the Sun's gender, as it is not in effect a crucial factor; especially if we regard Venus as standing for the two abstract qualities of beauty and love. It is the third sentence whose vague phraseology obscures an otherwise clear classical / mythical allusion, and so forces the translator, yet again, to avoid the precise reference to the Sun's gender. As the play has never been translated into Arabic, we have only the excerpts in Harold Bloom's Book Shakespeare: The Invention of the Human, 1998 and translated by Enani. As part of the invocation to Venus, the above lines have been thus rendered by him into Arabic verse:

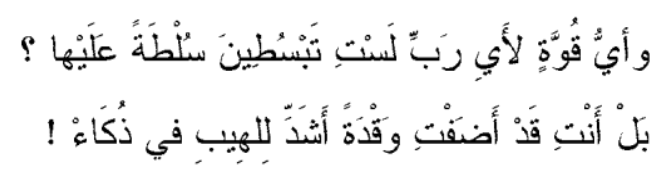




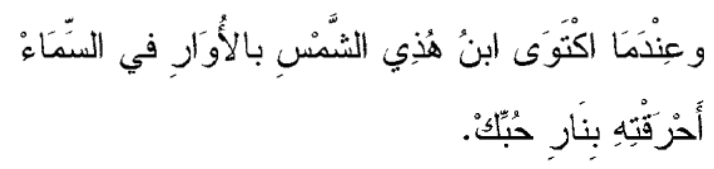

The translation is obviously acceptable as a verse rendering containing the mail figures of speech, but, apart from using an Arabic apparent equivalent to Phoebus, namely

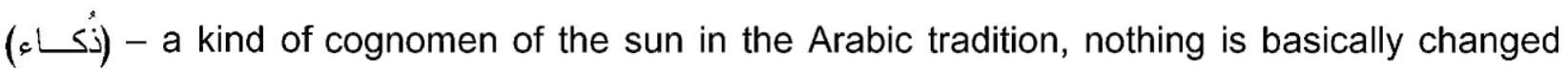
and the elucidation in the final line where "your fire" becomes "the first of your love" does not remove the ambiguity of the source text. The question of overcoming the gender obstacle remains unsolved. Day-Lewis's "consecrated images" are not, apparently, easy to translate.

The problem of gender is not to be sneezed at, for the Arabic translator has to find the proper pronouns for each "agent" in the Shakespearean text. Another example from the same play poses the same problem, though more seriously this time. Theseus is invoking "Heavenly charmers", and Bloom says they "scarcely seem Venus, Mars, and Diana; something more whimsical is being evoked" $(1998,713)$. Earlier in the book Bloom describes the passage in which the invocation occurs as "the last lines of serious poetry that Shakespeare ever wrote" (p. 697). Let us just have the first few lines containing the case of the problematic gender:

O you heavenly charmers,

What things you make of us ! For what we lack

We laugh, for what we have we are sorry, still

Are children in some kind.

$$
\text { (V. iv. 131-134) }
$$

Action on instinct, a Translator may immediately assume that the heavenly charmers are angels of some sort and, as angels, they are neuter, and Arabic neuter is regarded as more masculine than feminine. The Arabic (مََ ) ( $)$ is both singular and plural in the Quran, while (مـ (S) does not occur in the Muslim's holy book. One is also reminded of the magicians' encounter with Moses on his mission to Pharaoh. Consequently, the initial impulse is to translate the opening line as:

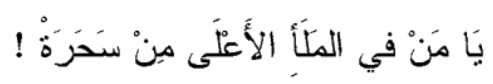


But vying with this image will be that of the Witches in Macbeth, and in the English popular tradition. They also appear as feminine in the Quran (النفاثات في العقـد); can one then be "forgiven" if one thought of them as feminine? Is Enani's version acceptable?

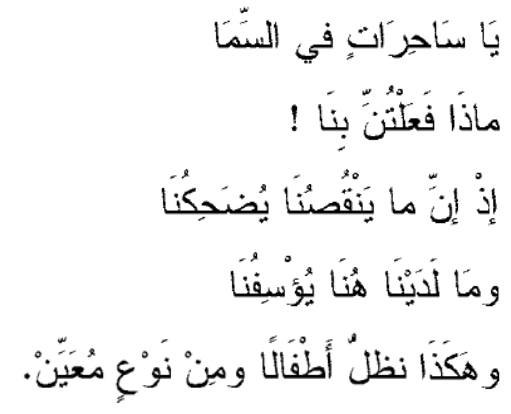

This is, no doubt, a moot point: Some readers will accept the Arabic version as, carried away by the lilting rhythm and the supererogatory rhythm, they fail to notice the gender of the addressee. Others will take issue with the translator on assuming a feminine gender when none is indicated by Shakespeare. There may be others who will allow both readings of the image, much in the same way as the sprite Ariel in Shakespeare's The Tempest, though presumably genderless, is often played by a girl on the stage and in the cinema. The gender identity of Ariel cracks the whole issue of gender in Shakespeare wideopen. The next stop is inevitably, therefore A Midsummer Night's Dream where one meets another kind of trope which may be described as a concrete dramatic trope. However, one needs first to establish the kinds of figures of speech handled in the previous two examples, cited from such a late Shakespearean text, from a "Translation Studies" perspective.

The figurative constructs in both texts belong to the mythological / classical-allusive type. By itself, the attribution of excessive power to an imaginary goddess is a hyperbolic image of man's capacity for love and for being destroyed by love. In itself, the figure is almost too trite, but it acquires a fresh significance from the ability of one god (Venus) to "scorch" another, the son of the Sum God. This apparent symbolic action can be felt, if simplified, to be grotesque. Solar fire, it says, is being burnt by the mightier fire of love - an "action" impossible to visualize. In his Meaning of Shakespeare, 1951, Goddard dismisses the image as pompous, and Bloom judges the whole Venus invocation as a "most unsavory utterance" (1998, p. 708). Apart from declining to tell us the object of Phaethon's love (Who 
is the fire being scorched by fire) Shakespeare doesn't tell us how this "allegory of love" works. Nor can going back to the original myth, say, in Ovid, help: versions of this fanciful incident occur in and outside Ovid. Now the Arabic texts given above seem to read well enough and, most importantly, make sense to the average Arab reader, so that one is forced to examine what the translator has done. The translator has in effect oversimplified the total "tropic" structure of both texts by all personifications of the sun god: instead of Phoebus we have first an alternative name in classical Arabic for the sun (namely ذُكــ which etymologically means burning bright) and, secondly, the actual name in the following line (الشمس). The image may have gained in clarity in the target text, but at a price, namely losing the implied oxymoron of fire consuming fire. Discouraged, perhaps, by the low opinion the critics have of this image, the translator would not spend too much time on it. Before moving on to the Dream, we should note above, they differ in structure, as the first moves in a crescendo to a climax, while the second relies on parataxis of an advanced type, reaching its climax through a cumulative effect.

When we reach Act III, scene I, in A Midsummer Night's Dream, we realize that a different kind of trope is being attempted by Shakespeare, namely the use of the metatheatrical trick of the rehearsals (for the play within the play) as an occasion for what I have called a concrete dramatic trope. In essence, as Shakespeare, the actor-playwright, knew well enough, all acting is "tropic", as someone comes onto the stage to tell us he or she is someone else. The idea of having a persona itself, that is wearing a mask, means that we see someone or something in terms of another - which is what metaphor is all about. This device is practiced implicitly throughout Shakespeare, and often quite explicitly when a girl is dressed as a young man, say in Twelfth Night or in As you like it; even in Hamlet where the protagonist puts on an "antic disposition" - a persona of sorts. Here, however, the poor mechanicals are only too aware of their persona, and some of them suggest they reveal their real identities to the audience. In fact, Puck's plan in The Tempest to change Bottom's head into the head of an ass is simply his concrete dramatic way of saying "you are an ass! "In other words, the verbal metaphor has turned into a physical trope: Puck exits with Bottom at 
III. i. 90, then re-enters at III. i. 107 with Bottom having acquired the head of an ass. Snout, his colleague, is shocked to see the change and asks Bottom "What do I see on thee ?" Bottom's reply is most unexpected: "What do you see ?" he says, "You see an ass-head of your own, do you?".

When Titania, the Fairy Queen, wakes up, she is totally under the influence of the magical power of the flower's juice, dropped in her eyes by Puck, and so falls in love with the first "thing" she sees - who happens to be Bottom with the ass-head. The situation is naturally hilarious, but its special significance lies in the metaphoric framework of the action. One may say bluntly that the Fairy Queen is in love with an ass, and Bottom's comment soon confirms the oddity, "reason and love keep little company together these days" (147). Bottom regards this remark of his as a joke - the only way such an anomaly can be explained away. His attitude to Titania's dotage is amiably innocent, and his child-like behavior becomes quite impressive as he is fascinated by the four little elves. This is the main difficulty which the Arabic translator must encounter. Guided by modern interpretations, the translator may choose to imagine the elves as young girls, calling each (جنــ), and so build up an orgiastic scene, as suggested by lan Richardson's film or Peter Brooke's stage production. The point is, however, Arabic has no equivalent for the hosts and variety of such spiritual creatures which people the Western Landscape - a topic worthy of a closer look.

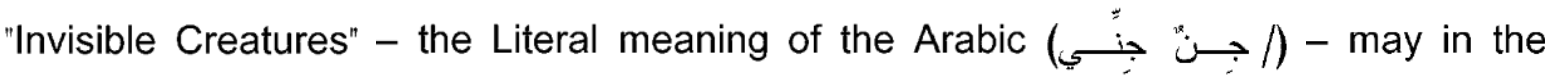
Western imagination be divided into two large categories: small ones and big ones. In the Eastern imagination, particularly our own, the first category is lacking, almost completely. All our jinn (singular $=$ a jinni $=$ a genie) are big: they vary in size in our folklore from the normal, (that is, the average) human figure to that of giants and supernatural demons. In Arabic we refer to them generally as jinn that is the invisible spiritual inhabitants of our world, and they may be good, i. e. benign (devoutly worshipping God) or wicked. In the latter case they are described as the descendents of the Devil, that is Satan. A single jinni - a genie -

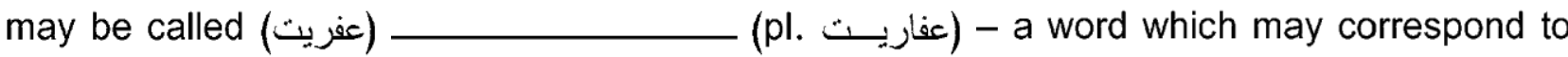
many English terms (1) a demon a spirit, or a sprite; (2) a ghost, a phantom, or an 
apparition. The most common fairies in the Western literary tradition are the small ones: (1) a pixy, pixie; (2) elf (pl. elves) and (3) a fay, the contraction used in poetry for fairy. They are all tiny spiritual creatures and are generally benign, with the exception of elves which may be mischievous. Finally, there are (4) goblins or hobgoblins which constitute a category by themselves, being ugly and evil looking spirits or mischievous demons.

Obviously, it is futile to try to establish any kind of correspondence between the Western and Eastern varieties of Spirits except at the level of big jinn; the translator's attempt to represent the Shakespearean scene with any degree of "faithfulness" may founder unless another means of describing the small fairies is found. Earlier translators simply wrote the names of the four pixies in Arabic characters, a perfectly legitimate way of dealing with

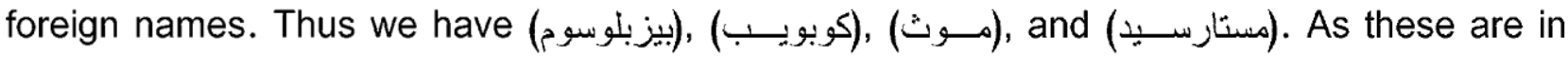
effect not proper names, nor do they occur in any other work by Shakespeare, or by any other writer, for that matter (Bartlett's Concordance has no other instances outside The Dream) one is justified in believing them to be meaningful epithets, nominally used. A general quality common to all (pace Richardson and Brook) is their genderlessness.

Now the Arabic translator of the play must establish initially whether to regard the fairies as feminine or masculine (or, if possible, neuter). To treat an inanimate object as a neuter (جــاد) is almost impossible in Arabic: every neuter must be treated as a putative feminine or masculine, much in the same way we refer to the ship in English as "She" and to one's car, if it one's pride and joy, as she, and to any dog as "he" unless one knows it is a bitch. However, all plurals of mainly inanimate objects (but also of persons) use a verb with a feminine ending. You say (هذه الجان) whether the singular is (جنية) / جني) or in the same way as in idiomatic Arabic you say (هذه الكتب) (these books), "أمدح بيث قالته العرب" "the best line of Arabic verse in panegyric" "a mouthful, isn't it ?" and in the Quran (تلـك الرسـلـ) (these messengers / apostles).

Exploiting this feature, the translator could have regarded all the fairies in Bottom's company as female. There is another feature of Arabic which allows one to use the feminine pronoun reserved for human females in referring to inanimate objects, animals and plants. 
The Quran uses the "human" plural feminine pronoun (هُنَّ) and the way it effects the inflection of verbs, in the famous verse enjoining Muslims to do "pilgrimage" ( ولى كل ضامر يأتين من كل (فج عميق . This "licence" has allowed the translator to regard Oberon's command to the fairies in the concluding lines of the play as though addressed to a feminine retinue, although Oberon explicitly addresses them as males:

With this field-dew consecrate

Every fairy takes his gate

And each several chamber bless

Though this palace, with sweet peace;

(V. i. $417-420)$

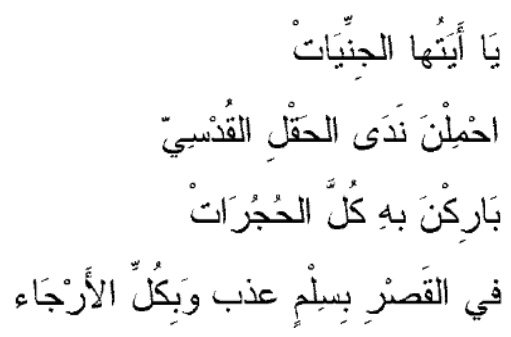

(Enani's translation, $2^{\text {nd }}$ edn. Cairo, 2008)

This so-called "licence" does not help the translator in handling the four elves in Bottom's company, especially as the translator has chosen to translate, rather than Arabize, their names. As it is, the Arabic names of the elves will up to a point determine their sex: so that in the process, two of them may seem masculine, the other two feminine. To banish any possibility of suggesting any pederastic, or, worse still, pedophilic tendencies in bottom's attitude to the "little ones" (as they are popularly called in the north of England) however, Shakespeare sees to it that Bottom insists on regarding the elves as masculine. Titania first asks her elves for serve Bottom, she gives us their names in order of preference, or seniority:

Tita. I am a spirit of no common rate;

The summer still doth tend upon my state;

And I do love thee: therefore go with me.

I'll give thee fairies to attend on thee; 
And they shall fetch thee jewels from the deep,

And sing, while thou on pressed flowers dost sleep:

And I will purge the mortal grossness so,

That thou shalt like an airy spirit go.

Peaseblossom ! Cobweb ! Moth ! And Mustardseed !

$$
\text { (III. i. } 147-155)
$$

And here is the Arabic:

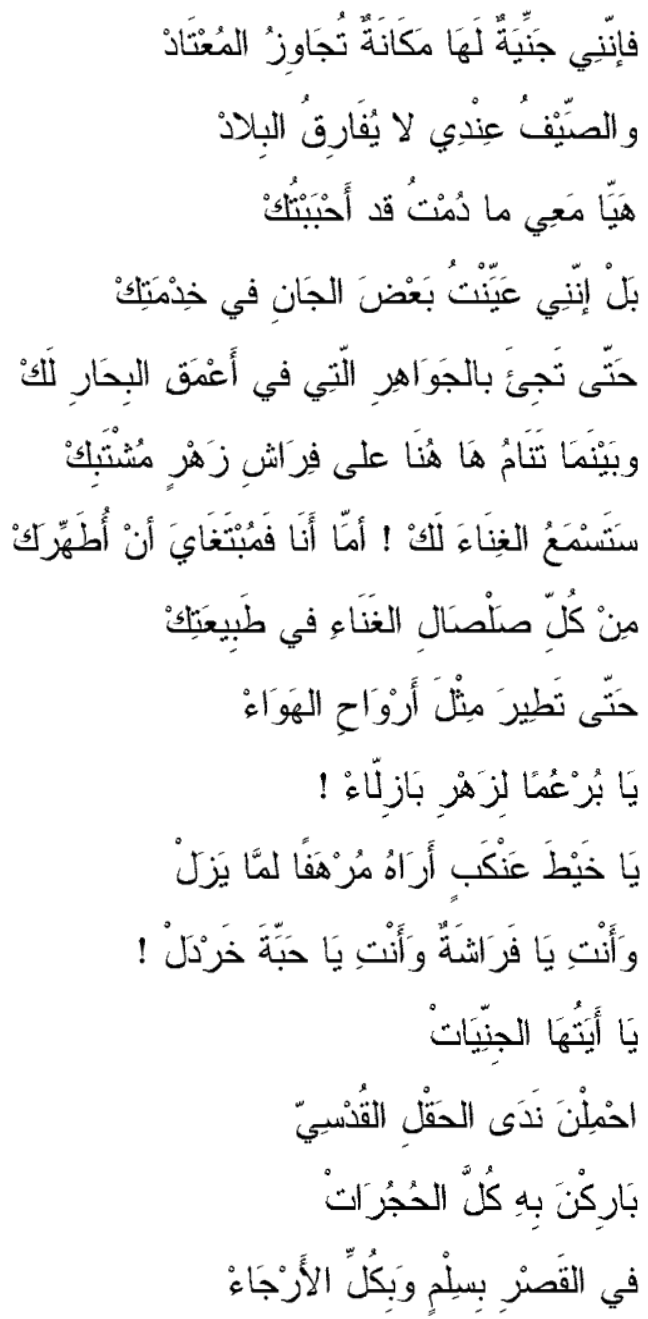

The genderization of the elves in Arabic cannot be seen to be significant as it is simply dictated by the nature of Arabic. In Arabic we often have a single name for a given species, such as (بطة) and the plural (بطة): We have no equivalent of "drake", as is the case with goose (إوزة) and the plural (الإوز) - no gander there. Again it happens that (فر انشة) can mean "moth" and "butterfly", with no word for the masculine. The Arabic for mustardseed is ( حبة 
canonized by reference to it, as a most minute thing, in the Quran. This division into male and female is obviously arbitrary, being only linguistically engendered. When a poet wants to describe a gender, he says:

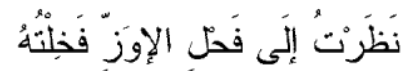

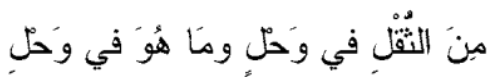

(Looking at a gender I thought it was trudging through deep mud, though no mud was there).

Having called on the elves and given them their order of the day, Titania Specifies what they are commanded to carry out; dealing with them as though they were "men" of some sort. She thus helps Bottom to deal with them indiscriminately as masculine. Here is first what she says:

Tita: Be Kind and courteous to this gentleman;

Hop in his walks, and gambol in his eyes;

Feed him with apricocks and dewberries,

With purple grapes, green figs, and mulberries,

The honey-bags steal from the humble-bees,

And for night-tapers crop their waxen thighs,

And light them at the fiery glow-worms' eyes,

To have my love to bed, and to arise,

And pluck the wings from painted butterflies

To fan the moonbeams from his sleeping eyes.

Nod to him, elves, and do him courtesies.

$$
\begin{aligned}
& \text { (III. i. 161-171) }
\end{aligned}
$$

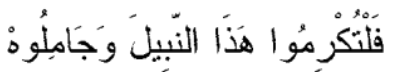

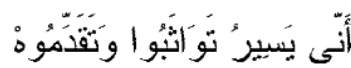

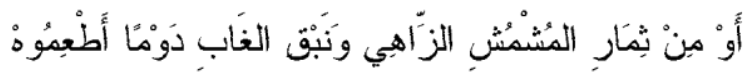

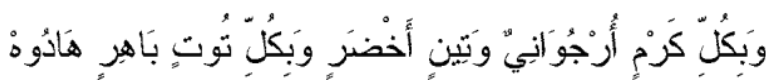

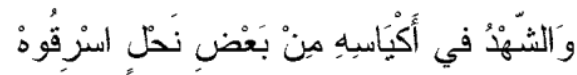




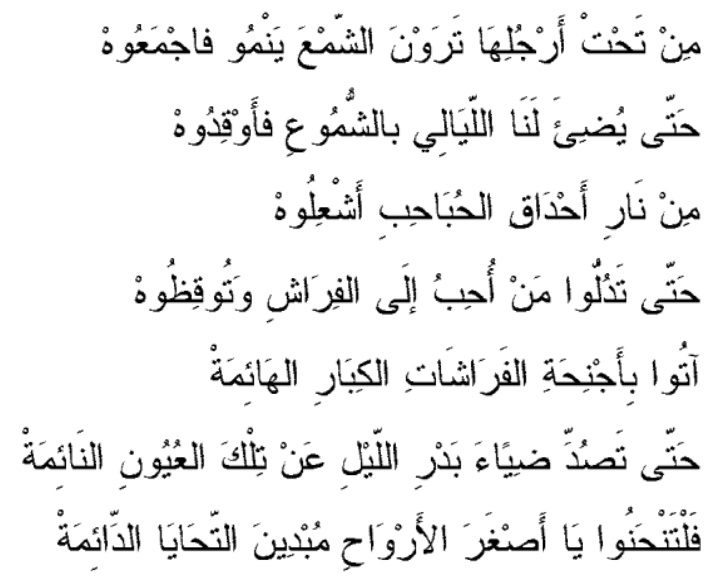

Here we have a well-wrought rhyme scheme, so rare in Shakespeare, where in the source text 10 lines share the same rhyme, echoed by only 9 in the Arabic text, though this missing rhyme is more than made up for by the 3- line coda, containing a couplet, consisting, as it happens, of two lines of fine feet each (خمس تفعيلات) and a strong rhyme. It is too flowery, even too artificially written-up, to suggest a serious human emotion attributed to the Fairy Queen. The crucial line in this memorable passage is line 8 in the English text, corresponding to line 9 in the Arabic, where the phrasing may suggest an envisaged sexual relation. Such a hint as this has led some critics. In Act four, however, such an orgiastic reading "is prophetically dismissed by the first scene, where Titania sits the amiable Bottom down upon a flowery bed, caresses his cheeks, sticks musk roses in his head, and Kisses his ears", as Harold Bloom says, adding that "this scarcely arouses Bottom to lust" (1998, p. 164). In fact any orgiastic reading is forestalled by the fact that Bottom treats all elves as masculine, totally ignoring any supposed signs of seduction, even if it was thought to have been shown by Titania's charming retinue. Instead, Bottom seems amused by the company he finds himself in, and concentrates on the strangely named little ones. This happens early enough, that is in Act III, long before the hilarions scene in Act IV. The following conversation follows the lines just quoted by Titania, and should clear Bottom of any "unsavoury" even if Titania could have had such "desires" (as may be shown by what follows this dialogue):

Peas: Hail, mortal !

Cob: Hail ! 
Motb: Hail !

Mus: Hail !

I cry your worships mercy, heartily. I beseech your

Bot: worship's name?

Cob: Cobweb.

Bot: I shall desire you of more acquaintance, good Master Cobweb: if I cut my finger, I shall make bold with you. Your name, honest gentleman.

Peas: Peaseblossom.

Bot: I pary you, commend me to Mistress Squash, your mother, and to Master

Peascod, your father. Good Master Peaseblossom, I shall desire you of more acquaintance too. Your name, I beseech you sir?

Mus: Mustardseed.

Bot: Good Master Mustardseed, I Know your patience well. That same cowardly giant-like ox-beef hath devoured many a gentleman of your house. I promise you, your Kindred hath made my eyes water ere now. I desire you of more acquaintance, good Master Mustardseed.

(III. i. 172-189)

And here is the prose rendering as published (by Enani):

$$
\begin{aligned}
& \text { برعم باز لاء : مرحبًا يا ابن البشر ! } \\
& \text { خبط العنكبوت : مرحبًا }
\end{aligned}
$$

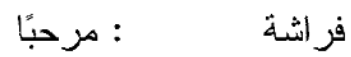

$$
\begin{aligned}
& \text { بذر الخردل مرحبًا } \\
& \text { بوطوم أرجوكم يا أصحاب السمو أن ترحموني ! أتوسل إليك با صاحب } \\
& \text { أن تخبرني من أنت }
\end{aligned}
$$




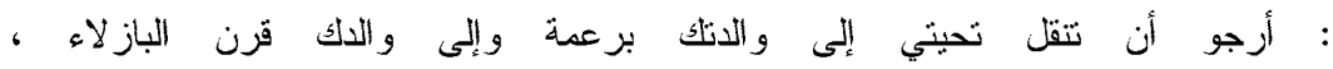

$$
\begin{aligned}
& \text { وأرجو أن ازداد معرفة بك أبضًا با أستاذ برعم. وأنت بيا سبد ، ما اسمك بك } \\
& \text { لو سمحت } \\
& \text { بذر الخردل خردل ! }
\end{aligned}
$$

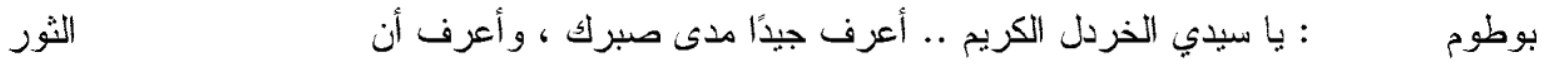

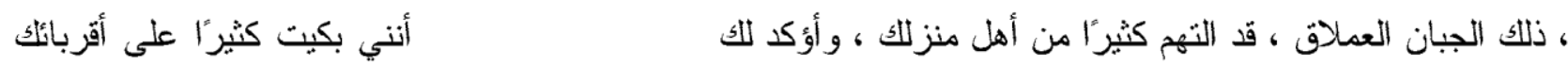

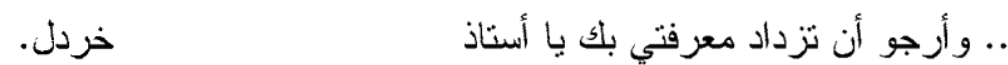

Obviously, the translator does his best to maintain the sex of the elves as perceived by Bottom, that is, as masculine. Three are addressed with the title of "Good master" and one as "your worship", a title reserved in the world of mortals either for addressing a magistrate or a mayor. Apart from establishing the fact that Bottom feels he is addressing those higher in rank than himself, the lines are crowned by Titania's express wish to be with Bottom in her bower:

Come, wait upon him, lead him to my bower.

The moon methinks looks with a watery eye;

And when she weeps, weeps every little flower, Lamenting some enforced chastity,

Tie up my love's tongue, bring him silently.

$$
\text { (III. i. 190-194) }
$$

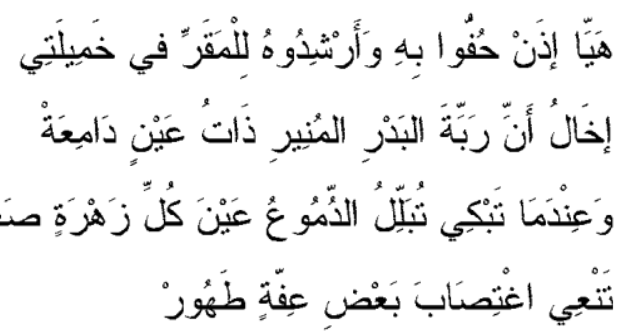

$$
\text { خبط العنكبوت : خبط العنكب }
$$

$$
\begin{aligned}
& \text { بوطوم : أرجو أن ازداد معرفة بك با باستاذ خبط ! و عندما أجرح إصبعي } \\
& \text { فسوف ثتوثق علاقتي بك ... وأنت أيها السبد الكريم ما اسمك ؟ } \\
& \text { برعم بازلاء : برعم بازلاء ! }
\end{aligned}
$$




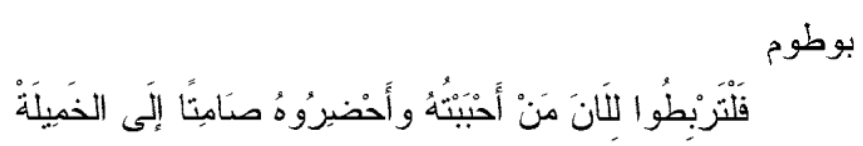

With all due respect to what Harold Bloom thinks, critics are justified in sensing the presence of a desire to make love to Bottom on the part of Titania. However unconsciously expressed. Even as parapraxia. In the line envisaging her intended "rape" of the chaste Bottom, line 193 above. It is as though Diana, the moon Goddess, as the preserver of chastity already laments what Titania has in mind. The fact that this never happens is due to Bottom's handling of the elves as masculine in Act IV, scene I, as is shown below. This is the decisive scene, culminating in Bottom's going to sleep:

Bot: Where's Peaseblossom. Where's Mounsieur Cobweb ? Peas: Ready.

Bot: Scratch my head, Peaseblossom. Where's Mounsieur Cobweb ?

Cob: Ready.

Bot: Mounsieur Cobweb, good mounsieur, get you your weap in your hand, and Kill me a red-hipped humble-bee on the top of a thistle; and good mounsieur, bring me the honeybag. Do not fret yourself too much in the action, mounsieur; and good mounsieur, have a care the honey-bag break not. I would be loath to have you overflowen with a honey-bag, signior. Where's Mounsieur Mustardseed?

Mus: Ready.

Bot: Give me your neaf, Mounsieur Mustardseed. Pary you, leave your courtesy, good mounsieur.

Mus: What's your will ?

Bot: Nothing, good mounsieur, but to help Cavalery Cobweb to scratch. I must to the barber's, mounsieur, for methinks I am marvelous hairy about the face; and I am such a tender ass, if my hair do but tickleme, I must scratch.

Tita: What, wilt thou hear some music, my sweet love ?

Bot: I have a reasonable good ear in music. Let's have the tongs and the bones.

Tita: Or say, sweet love, what thou desir'st to eat? 
Truly, a peck of provender; I could munch your good dry oats. Methinks I have a great desire to a bottle of hay: good hay, sweet hay, hath no fellow.

Here is what the published translation says:

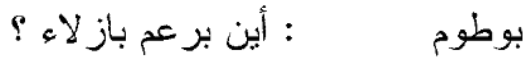

$$
\begin{aligned}
& \text { برعم باز لاء حاضر . } \\
& \text { بوطوم اهرش رأسي يا بازلاء. أبن المسيو خيط عنكبوت ؟ } \\
& \text { خبط العنكبوت : حاضر. }
\end{aligned}
$$

بوطوم م : مسيو خبط عنكبوت ! أيها المسيو الكريم ! جهز أسلحتك واستعد حنى تقلل النحلة الني تقف فوق الثوكة ، وأردافها حمراء. ثم أحضر لي أيها المسبو الكريم قرص العسل ، و لا تجهد نفسك كثبرًا في العمل با مسيو ! وحذار با مسيو أن بنكسر منك قرص العسل ، فلا أحب أن بغمرك العسل با سنيور ! أين المسيو بذر الخردل !

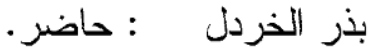

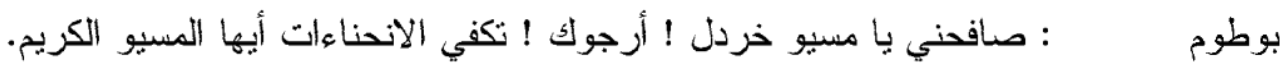
بذر الخردل ماذا تزريد ؟ بوطوم : لا شئ أيها المسيو الكريم ، وسى مساعدة الفارس الهمام ، المسبو خبط عنكبوت ، في هرش رأسي. لابد أن أذهب إلى الحلاق يا مسيو ، فأظن أن الثعر الكثثف يغطي وجهي ، وأنا حمار

$$
\begin{aligned}
& \text { حساس ، ما إن أشعر بدغدغة حتى أسر ع إلى الهرش ! } \\
& \text { تيتانبا : هل نود الاسنماع إلى بعض الموسيقى با حبيبي الظريف ؟ }
\end{aligned}
$$

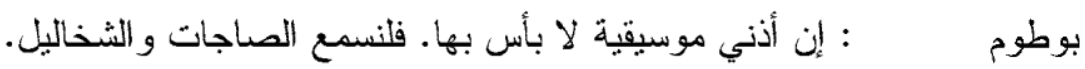

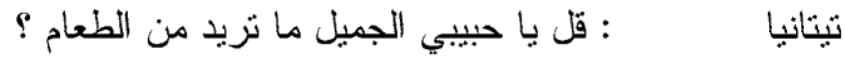

$$
\begin{aligned}
& \text { بوطوم في الحقيقة .. قليل من العلف. أشتهي بعض الشوفان الجاف المنتاز . و أظن أنني أشتهي شرابًا } \\
& \text { من الدريس. اشتهيه جدًا. فالدريس الجميل .. الدريس اللذيذ لبس له أخ. }
\end{aligned}
$$

In the course of Act III, the mixed genders of the fairies are maintained in the Arabic translation, up to line 155 where Titania summons them, calling on them by their names , as we have seen. If on demands consistency as a criterion for judging the translation of gendered figures of speech in Shakespeare, one will be totally disappointed. If the translator is tempted to achieve consistency by opting for a single gender for all such airy and invisible 
Bot:

creatures, either male or female, the target text will, paradoxically, not be consonant with the source text which gives us mixed genders. The translator of the cited excerpts, M.Enani , in

his first Arabic version of A Midsummer Night's Dream, published in Al-Masrah ( The Theatre ) back in 1964 , gave us a cast of all female fairies ; but, in the revised version of the translated play $(1992,2008)$ he apparently changed some gender reference to them as males, so as to reflect Bottom's perspective, while keeping most of the original references intact. By examining each and every each reference in context, one may conclude that the revision has not achieved the sought-after consistency.

\section{References:}

- Arendt, Hanna. Martin Heidegger at 80, in Murray, M. (ed) Heidegger and Modern Philosophy.

- Yale University, 1978.

- Austen, John. How to do Things With Words. Harvard University Press, Cambridge, Massauchusetts. 1962.

- Bloom, Harold. Shakespeare: The Invention of The Human. Fourth Estate publishing, 1998. Brooke-Rose, Christine. A Grammar of Metaphor. London university press, 1958.

- Cassirer, Ernst. Philosophy of Symbolic Forms: Mythical Thought. Yale University Press, 1923.Day-Lewis, Cecil. Poetic Image. Bloomsbury publishing, London, 1947.

- Fineman, Joel. Shakespeare's Perjured Eye: The Invention of Poetic Subjectivity in his Sonnets.University of California Press Berkeley, 1996.

- Goddard. Meaning of Shakespeare. Chicago University Press and London, 1951. Halliday's, Michael. Functional Grammar. Birmingham, UK University press, 1985. Heylen, Romy. Translation, Poetics and the Stage. Routledge Library, 1993.

- Marsh, Florence. Wordsworth's Imagery: A Study in Poetic Vision. Cornell University press, 1952 .

- Ning, Wang, and Sun Yifeng, eds. Translation, Globalization and Localization: A ChinesePerspective. University of Massachusetts, Amherst, 2008.

- Richards, Ivor Armstrong. Philosophy of Rhetoric. Routledge Taylor and Francis, 2001.

- Schoenfeldt, Michael. Companion to Shakespeare's Sonnets. Blackwell A John Wiley and Sons,Ltd, Publishing,2007. 
- Spurgeon, Caroline. Shakespeare's Imagery and what it Tells Us. Cambridge University press, 1936.

- Susan Bassnett and Andre Lefevere. Constructing Cultures. University of Warwick, 1998.

- Vendler, Helen. The Art of Shakespeare's Sonnets. The Belknap press of Harvard universitypress, California, London, England, 1964.

- White, Hayden. The Tropics of Discourse. The Johns Hopkins University press, 1978.

- $\quad$ Rosemary MARTIN, CRITICAL REFLECTIONS ON DANCE EDUCATION IN THE SOUTHERN MEDITERRANEAN FROM 2010 TO 2020, International Journal of Creativity and Innovation in Humanities and Education, Vol. 3 No. 1, 2020, pp. 1-16.

Received: September 00, 2020

Accepted: November 00, 2020 